\title{
ВПЛИВ ВРАЖАЮЧОЇ ДІЇ ОСКОЛКОВИХ БОЄПРИПАСІВ НА ЕЛЕМЕНТИ ОБ'ЄКТІВ І ЛЕГКО БРОНЬОВАНУ ТЕХНІКУ ПІДРОЗДІЛІВ
}

Аналіз проведених досліджень показав, що найбільш ймовірними засобами ураження елементів об'єктів і легко броньованої техніки підрозділів є артилерійські системи, що ведуть вогонь осколково-фугасними боєприпасами, в тому числі ті, що мають порівняно високу точність влучання на позицію підрозділу і велику руйнівну силу. Тому в статті представлений аналітичний вираз, що описується законом Пуассона та характеризує ймовірність ураження елемента ОВТ одним осколком, що потрапив в нього. Він може бути використаний як для оцінки вражаючої дї̈ осколкових боєприпасів на живучість елементів об'єктів і легко броньованої техніки підрозділів так і для оцінки вражаючої дії осколкових боєприпасів на живучість ОВТ в цілому.

Ключові слова: осколкові боєприпаси, легко броньована техніка, боєприпаси, ймовірність ураження, закон Пуассона.

\section{Вступ}

Постановка проблеми. Аналіз проведених досліджень показав, що найбільш ймовірними засобами ураження елементів об'єктів і легко броньованої (ЛБТ) техніки підрозділів $\epsilon$ артилерійські системи, що ведуть вогонь осколково-фугасними боєприпасами. Ймовірність їх поразки зазвичай визначається експериментально, або шляхом обробки накопичення в ході бойових дій в статистичних даних, а також методом натурального фізичного моделювання.

Зазначені методи складні, дорогі і не завжди прийнятні, так як достатня кількість експериментальних даних може бути отримана тільки після тривалого бойового використання озброєння та військової техніки (ОВТ). На жаль, під час проведення ATO (OOC) такі дані не були занотовані, а в мирний час ці методи не задовольняють вимоги підготовки системи військового ремонту. Метод натурального моделювання вимагає виготовлення точних моделей OBT, що невигідно із економічних міркувань. Крім того вони неприйнятні для нових типів ОВТ і зовсім не підходять для тільки що сконструйованих ОВТ.

Тому в статті запропонований аналітичний вираз, що описується законом Пуассона та характеризує ймовірність ураження елемента об'єктів і ЛБТ техніки одним осколком, що потрапив в нього.

Аналіз останніх досліджень і публікацій. Результати проведеного аналізу наукових джерел показали, що відповідно до проведеного дослідження існуючих типів боєприпасів найбільш ймовірними засобами ураження елементів об'єктів і ЛБТ підрозділів є артилерійські системи, що ведуть вогонь осколково-фугасними боєприпасами [1-2].
Таким чином для елементів об'єктів і ЛБТ підрозділів основним фактором поразки є осколки бойових частин осколкових боєприпасів $[1 ; 3]$.

Мета статті. Представити аналітичний вираз, який може бути використаний як для оцінки вражаючої дії осколкових боєприпасів на живучість елементів об'єктів і легко броньованої техніки підрозділів так і для оцінки вражаючої дії осколкових боєприпасів на живучість ОВТ в цілому.

\section{Виклад основного матеріалу}

Під впливом вражаючих факторів осколкових боєприпасів елементи ОВТ отримують різного роду пошкодження або руйнування. Вражаючими факторами при підриві боєприпасів $€$ [4-6] :

- газоподібні продукти вибуху;

- ударна хвиля;

- осколки корпусу;

- кінетична енергія рухомих боєприпасів.

Елементи об'єктів і легко броньованої техніки ЛБТ підрозділів, які вражають осколкові боєприпаси, можуть бути виведені з ладу наслідком дії кожного $з$ перерахованих факторів окремо або їх спільної дії в залежності від точності попадання боєприпасів, потужності і властивостей їх бойових частин, а також від міцності властивостей самих об'єктів. Елементи об'єктів і ЛБТ підрозділів можуть бути вражені в результаті:

- фугасної дії під час вибуху боєприпасів в повітрі або на грунті;

- осколкової дії під час вибуху боєприпасів в повітрі або на поверхні перепони;

- кумулятивної дії при прямому попаданні боєприпасів в об'єкт; 
- ударної дії при прямому влученні боєприпасів в об'єкт або про проникнення боєприпасів в грунт;

- сейсмічної дії під час вибуху боєприпасів в грунті.

Із перелічених вражаючих дій найбільш небезпечними 3 точки зору оцінки ступеня пошкодження елементів об'єктів і ЛБТ підрозділів, а також можливості їх відновлення на місцях дислокації являються фугасна, осколкова і осколково-фугасна дія боєприпасів.

Звичайно, не менше небезпечні кумулятивні i ударні дії боєприпасів. Про те ці дії притаманні випадкам прямого влучання боєприпасів в елементи об'єктів і ЛБТ підрозділів, при яких останні отримують, як правило, повні або частково - повні пошкодження, які не можливо усунути на місцях розташування ОВТ. Тому за доцільне проаналізувати фугасну, осколкову і осколково-фугасну дію боєприпасів. Фугасною дією називають нищівну силу боєприпасу, що вибухнув в повітрі або грунті на деякій відстані від об'єкта (цілі). На відносно малих відстанях від центру вибуху боєприпасу до об'єкта фугасна дія обумовлюється дією газоподібних продуктів вибуху. При збільшенні цієї відстані вона являє собою спільну дію газоподібних продуктів вибуху і ударної хвилі, що утворилася під час вибуху. На досить великих відстанях фугасна дія обумовлена тільки дією ударної хвилі [7].

В результаті вибуху боєприпасу в повітрі або на землі утворюється ударна хвиля у вигляді стрибкоподібної зміни тиску, котра поширюється 3 надзвуковою швидкістю в усі сторони від точки вибуху. Зустрічаючи на своєму шляху наземні об'єкти, ударна хвиля завдає їм пошкодження механічного характеру впливом свого надлишкового тиску на конструктивні елементи об'єктів і ЛБТ підрозділів. Поводження матеріалів під впливом такого короткочасного у часі навантаження та визначення ступеня руйнівної дії ударної хвилі представляє важку задачу. Взагалі, ступінь пошкодження об'єкта ударною хвилею визначається наступними факторами:

- властивостями заряду, що визначають його руйнівну здатність: потужністю питомої енергії вибухової речовини, вагою заряду, а в деяких випадках формою заряду;

- властивостями цілі: іiі формою, розмірами, міцністю матеріалу, міцністю цілей як конструкції і іiі опірністю до руйнівної дії вибухового навантаження;

- відстанню між зарядом і ціллю.

I 3 накопичених практичних даних випливає, що безпосередній вплив продуктів вибуху проявляється на відстанях, рівних 12-16 радіусах дії заряду, а спільна дія продуктів вибуху і ударної хвилі проявляється на відстанях до близько 20 радіусів дії заряду [7; 9]. Радіус дії може бути знайдений за допомогою формули:

$$
R_{o}=\sqrt[B]{\frac{3}{4 \pi \beta_{B B}} M},
$$

де $\beta_{B B}$ - густина вибухової речовини боєприпасу;

$M$ - маса заряду.

Результати розрахунків за формулою (1) радіусів дії зарядів боєприпасів, що широко застосовувались для нанесення ударів по елементам об'єктів і ЛБТ підрозділи в ході бойових дій, показує, що радіуси дії продуктів вибуху цих боєприпасів лежать в межах 4-6 м., а радіуси спільної дії продуктів вибуху і ударної хвилі 5-8 м.

I 3 досвіду бойових дій, в тому числі АТО (ООС) відомо, що кругові помилки точок влучання мінометних мін калібру 82 мм. і 120 мм., а також 122 мм. фугасні снаряди гаубиці Д-30 і 152 мм. фугасні снаряди самохідної гаубиці 2С3 становить 50500 м. Таким чином видно, що розміри зони дії продуктів вибуху і ударної хвилі порівняно невеликі по відношенню до круговим помилок точок попадання осколкових боєприпасів. Це дає підставу вважати, що фугасна дія не є основним вражаючим фактором для елементів об'єктів і ЛБТ підрозділу. У переважній більшості випадків елементи об'єктів і ЛБТ підрозділів уражаються осколковим діями осколкових боєприпасів.

В результаті вибуху розривного заряду боєприпасів крім продуктів вибуху і ударної хвилі утворюється велика кількість осколків - продуктів дроблення корпусу боєприпасів. Осколки, що утворилися розлітаються в різні боки від точки вибуху і при попаданні в ціль здатні нанести різного роду пошкодження.

Ефективність осколкової дії залежить в першу чергу від таких конструктивних параметрів самої бойової частини боєприпасу, як загальна вага, коефіцієнт наповнення, форма і властивості металу корпусу, властивості вибухової речовини, особливості конструкції і т.д. Всі ці конструктивні параметри визначають характер дроблення корпусу на осколки (вагу осколків, що утворюються під час вибуху та їх загальну кількість), початкову швидкість осколків і характер їх розльоту в просторі.

Ефективність осколкової дії визначається також властивостями цілі, по якій проводиться стрільба, а саме сумарною площею цілі, площею різних вразливих деталей, елементів і агрегатів та їх опірність вражаючій дії осколків. Також ефективність осколкової дії істотно залежить від відстані до цілі, від орієнтації осі боєприпасу щодо цілі, тобто, від кута зустрічі 3 площиною землі. Отже, в умовах обмеженої (локальної) війни із застосуванням противником звичайних засобів ураження елементи об'єктів і ЛБТ підрозділів більшою мірою отриму- 
ють пошкодження від впливу осколків бойових частин цих засобів. Тому в роботі основна увага приділена питанню оцінки вражаючої дії осколкових боєприпасів на елементи об'єктів і ЛБТ підрозділу. В умовах артилерійського обстрілу ефективність ОВТ багато в чому визначається ії живучістю, бо живучість - це здатність ОВТ виконувати бойове завдання при вогневому впливі противника.

Живучість ОВТ може бути охарактеризована через ймовірність його поразки осколковими боєприпасами. Знання ймовірності поразки системи ОВТ в цілому і іiі елементів зокрема, дає ясну картину про характер і складність пошкоджень ОВТ, що заздалегідь дозволяє визначити можливий обсяг відновлювального ремонту і склад необхідних для його виконання ремонтних сил і засобів.

Для визначення ймовірності ураження цілі осколковими боєприпасами необхідно попередньо встановити в чому конкретно проявляється нищівна сила осколка, що потрапив в ціль.

Існує три основних види вражаючої дії осколків а [4]:

- пробивна дія (механічні пошкодження окремих вразливих елементів ОВТ);

- запалювальна дія (виникнення пожежі при влучанні осколка в баки з пальним і трубопроводи паливної системи, на легкозаймисті матеріали);

- порушення роботи електричних систем та систем управління (замикання електропроводки та перебивання осколками кабелів і проводів);

- ініціююча дія (детонація боєкомплектів бойових машин та інших боєприпасів при влучанні в них осколків).

Прояв того чи іншого виду вражаючої дії осколку обумовлюється конструктивним особливостями і складом ОВТ, наприклад, запальні дії характерні при попаданні осколків в ОВТ, що має в своєму складі паливні баки або інші легкозаймисті речовини, а ініціюють дії - при наявності в складі ОВТ вибухових речовин. Для таких об'єктів ураження ОВТ як моторні та бойові відділення ЛБТ вражаюча дії осколку проявляється в пробивній дії. Пробивна дія боєприпасів є найбільш типовою і разом з тим досить різноманітною та включає в себе такі види ураження, як різного роду механічні пошкодження окремих елементів ЛБТ (агрегатів, блоків, вузлів), які приводять їх до руйнування і виходу з ладу. При цьому пробивна дія осколків проявляється у вигляді механічних пошкоджень таких деталей елементів моторних і бойових відділень ЛБТ, як лампи, конденсатори, та інше, в обриві монтажних джгутів, перебиті електропроводки і т.д. Моторні та бойові відділення ЛБТ перестають функціонувати якщо будуть пошкоджені елементи, без яких їх застосування стає неможливим (тобто пошкоджені функціонально необхідні елементи) . тоді ймовірність ура- ження окремого моторного та бойового відділення ЛБТ можна пов'язати 3 ймовірністю ураження іiі елементів наступним співвідношенням:

$$
P_{y p_{л б m}}=1-\prod_{i-1}^{I}\left(1-P_{y p_{i}}\right),
$$

де $I$ - число функціонально необхідних елементів моторного та бойового відділення ЛБТ;

$P_{y p_{i}}$ - ймовірність ураження $i$-го елемента моторного та бойового відділення ЛБТ;

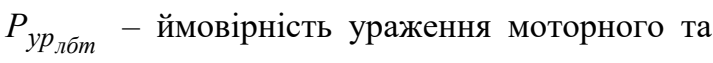
бойового відділення ЛБТ.

Співвідношення (2) справедливо в тому випадку, коли до складу ЛБТ входять тільки функціонально необхідні елементи, тобто елементи, які різняться за своєю структурою і функцією (їх можна назвати неоднорідними) і вихід з ладу хоча б одного з яких призводить до втрати працездатності ЛБТ.

Однак крім функціонально необхідних елементів до складу моторного та бойового відділення ЛБТ входять елементи однакової структури. В цьому випадку для ураження моторного та бойового відділення ЛБТ необхідно вивести з ладу не один а кілька таких елементів. Таким чином, ймовірність ураження моторного та бойового відділення ЛБТ може бути розрахована зі співвідношення:

$$
P_{y p_{\text {лбт }}}=1-\left[\prod_{i-1}^{I}\left(1-P_{y p_{i}}\right)\right]\left[1 \cdot C_{\kappa}^{\ell} P_{y p_{j}}^{\ell}\right],
$$

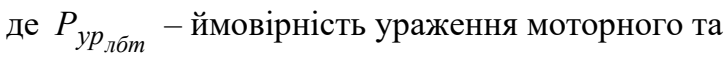

бойового відділення ЛБТ;

$P_{y p_{i}}$ - ймовірність ураження $i$-го функціонально необхідного елемента (неоднорідного);

$P_{y p_{j}}$ - ймовірність ураження $j$-го елемента однакової структури (однорідного);

$I$ - кількість неоднорідних елементів моторного та бойового відділення ЛБТ;

$\ell$ - число однорідних елементів моторного та бойового відділення ЛБТ, які треба уразити, щоб ЛБТ перестала функціонувати;

$K$ - загальна кількість однорідних елементів.

Якби число осколків, що потрапили в елемент моторного та бойового відділення ЛБТ, можна було визначити точно, то ймовірність ураження елемента можливо було розрахувати за формулою:

$$
P_{y p_{i}}=1-\left[1-P_{y p_{i}}(1)\right]^{n_{i}}
$$

де $P_{y p_{i}}(1)$ - ймовірність ураження $i$-го елемента одним потрапившим в нього осколком;

$n_{i}$ - число потрапивших в елементах осколків.

Практично при постійній середній густині осколків в потоці осколків мають місце деякі випадковим чином розташовані неоднорідності (“згустки”). По- 
ложення моторного та бойового відділення ЛБТ в осколковому полі також є випадковим. Отже, в розглянутий елемент може потрапити різне число осколків. 3 теорії ймовірності відомо, що якщо точки попадання осколків розподілені на площині статистично рівномірно і незалежно один від одного, то закон розподілу числа осколків, що потрапили в елемент, описується законом Пуассона [10]. Дослідні дані свідчать про те, що закон розподілу числа осколків, які потрапили в елементи, кутові розміри яких малі в порівнянні з шириною сектора розльоту осколків, дійсно близький закону Пуассона [11].

Так як сучасні засоби розвідки артилерійських підрозділів здатні забезпечити стрільбу з помилкою, більше, ніж розміри моторного та бойового відділення ЛБТ, то закон розподілу осколків на площині моторного та бойового відділення ЛБТ можна вважати законом Пуассона, а отже координатний закон ураження моторного та бойового відділення ЛБТ має вигляд [10-11].

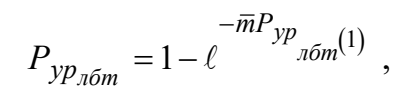

де $P_{y p}{ }_{\text {лбт }(1)}$ - ймовірність ураження моторного та бойового відділення ЛБТ одним осколком, який потрапив в нього; яка може бути визначена аналогічним чином із співвідношення (3), де під $P_{y p_{i}}(j)$ розуміється ймовірність ураження $i$-го $(j-20)$ елемента моторного та бойового відділення ЛБТ одним осколком, що потрапив в нього;

$\bar{m}$ - середнє число осколків, що уразили моторне та бойове відділення ЛБТ.

Зі співвідношень (3), (5) випливає, що для прогнозування пошкоджень моторного та бойового відділення ЛБТ як елемента ОВТ підрозділу необхідно обчислити ймовірності ураження іiі комплектуючих елементів одним осколком $P_{y p_{i}}\left({ }_{j}\right)^{(1)}$ i середнє число осколків, що потрапляють в моторне та бойове відділення ЛБТ.

\section{Висновок}

Ймовірність поразки елементів моторного та бойового відділення ЛБТ одним осколком зазвичай визначається експериментально, або шляхом обробки накопичення в ході бойових дій в статистичних даних, а також методом натурального фізичного моделювання.

Зазначені методи складні, дорогі і не завжди прийнятні, так як достатня кількість експериментальних даних може бути отримана тільки після тривалого бойового використання ОВТ. Але на жаль, під час проведення АТО (ООС) такі дані не були занотовані, а в мирний час ці методи не задовольняють сучасні вимоги підготовки системи військового ремонту. Метод натурального моделювання вимагає виготовлення точних моделей ОВТ, що невигідно із економічних міркувань. Крім того вони неприйнятні для нових типів ОВТ і зовсім не підходять для тільки що сконструйованих ОВТ.

Відповідно до проведеного дослідження існуючих типів боєприпасів найбільш ймовірними засобами ураження елементів об'єктів і ЛБТ підрозділів $\epsilon$ артилерійські системи, що ведуть вогонь осколково-фугасними боєприпасами, в тому числі ті, що мають порівняно високу точність влучання на позицію підрозділу і велику руйнівну силу. Результати проведеного аналізу наукових джерел показали, що для елементів об'єктів і ЛБТ підрозділів основним фактором поразки є осколки бойових частин осколкових боєприпасів. Тому в роботі ми отримали аналітичний вираз, що характеризує ймовірність ураження елемента ОВТ одним осколком, що потрапив в нього. Він може бути використаний як для оцінки вражаючої дії осколкових боєприпасів на живучість елементів об'єктів і ЛБТ підрозділів так і для оцінки вражаючої дії осколкових боєприпасів на живучість ОВТ в цілому.

\section{Список літератури}

1. Сучасне озброєння і військова техніка Збройних Сил Російської Федерації. Довідник учасника ООС. Корнійчук С. П. та ін.; за заг. ред. Корнійчука С. П. Харків : ХНУПС, 2020. 1220 с.

2. Brehm M., Borrie J. Explosive Weapons: Framing the Problem - final report. Geneva : GICHD, 2010. 145 p.

3. Сєдов С. Г., Бублій В. А., Ревуцький А. А. Аналіз та прогнози розвитку захисту легко броньованих бойових машин від дії стрілецької зброї. Труди університету. 2019. № 1. С. 129-137.

4. Сидоренко Ю. М. Особливості процесу вибухового метання осколкоутворюючих дисків, що входять до складу осколково-пучкового снаряда. Збірник наукових праиь Академї Військово-морських Сил ім. П. Нахімова. 2012. № 1(9). C. 86-99.

5. Метод аналітичної оцінки розмірів області розсіювання точок падіння бойових елементів після розкриття касетної бойової частини. Тарасов В. М., Журавльов О. О., Ізюмський М. П., Шигімага Н. В. Системи озброєння $і$ військова техніка. 2018. № 4(56). С. 60-66. https://doi.org/10.30748/soivt.2018.56.09.

6. Греков В. П., Журавльов О. О., Ткаченко Ю. А. Метод оцінки розміру приведеної площі осколкового ураження касетної бойової частини реактивного снаряду з осколково-фугасними бойовими елементами. Системи озброєння $i$ військова техніка. 2019. № 1(57). С. 77-84. https://doi.org/10.30748/soivt.2019.57.11. 
7. Аттетков А. В., Бойко М. М., Грязнов Е. Ф. Экспериментальные исследования влияния кривизны детонационного фронта на начальные параметры ударной волны в цилиндрической оболочке. Оборонная техника. 2004. № 1. C. $18-22$.

8. Оцінка ефективності осколкового ураження одиночної цілі одним пострілом у випадку наземного підриву осколково-фугасного снаряду. Ткаченко А. А., Соловйов В. І., Павленко А. Г., Копашинський С. А. Труди університету. 2016. № 3. C. 200-209.

9. Efficient Method to Evaluate Critical Ricochet Angle of Projectile Penetrating into a Concrete Target. Choi Min Kuk, Han Jihoon, Park Sangjin, Az Woo Jin. Mathematical Problems in Engineering. 2018. Vol. 2018. P. 12. https://doi.org/ $10.1155 / 2018 / 3696473$.

10. Кушнір О. О., Кушнір В. П. Дослідження властивостей високонадійної системи із захистом у випадку Пуасонівського процесу відновлення. Theory of Probability and Mathematical Statistics. 2017. № 96, С. 125-130.

11. Buchak K., Sakhno L. On the governing equations for Poisson and skellam processes time-changed by inverse subordinators. Theory of Probability and Mathematical Statistics. 2018. № 1(98), C. 87-99. https://doi.org/10.1090/tpms/1064.

12. Berko Zecevica, Alan Catovic, Jasmin Terzic, Kadic Sabina Serdarevic. Analysis of influencing factors of mortar projectile reproduction process on fragment mass distribution. New Trends in Research of Energetic Materials : XIII Seminar. Part II. Pardubice, Czech Republic, 21-23 Apr. 2010. Pardubice, 2010. P. 783-796.

Відомості про авторів:

Літвінчук Роман Валерійович

ад’юнкт Військової академії,

Одеса, Україна

https://orcid.org/0000-0002-5681-691X

Левченко Андрій Олександрович

кандидат технічних наук доцент

науковий співробітник Військової академії,

Одеса, Україна

https://orcid.org/0000-0001-5550-0027

Клименко Віктор Володимирович

кандидат технічних наук старший науковий співробітник доцент кафедри Військової академії,

Одеса, Україна

https://orcid.org/0000-0002-8073-4404
Information about the authors:

Roman Litvinchuk

Doctoral Student Military Academy,

Odessa, Ukraine

https://orcid.org/0000-0002-5681-691X

Andrii Levchenko

Candidate of Technical Sciences Associate Professor

Research Associate Military Academy,

Odessa, Ukraine

https://orcid.org/0000-0001-5550-0027

ViktorKlymenko

Candidate of Technical Sciences Senior Research

Senior Lecturer Department of Military Academy,

Odessa, Ukraine

https://orcid.org/0000-0002-8073-4404

\title{
ВЛИЯНИЕ ПОРАЖАЮЩЕГО ДЕЙСТВИЯ ОСКОЛОЧНЫХ БОЕПРИПАСОВ НА ЭЛЕМЕНТЫ ОБЪЕКТОВ И ЛЕГКО БРОНИРОВАННУЮ ТЕХНИКУ ПОДРАЗДЕЛЕНИЙ
}

\author{
Р.В. Литвинчук, А.А. Левченко, В.В. Клименко
}

Анализ проведенных исследований показал, что наиболее вероятными средствами поражения элементов объектов и легкобронированной техники подразделений является артиллерийские системы, ведущие огонь осколочнофугасными боеприпасами, в том числе имеющие сравнительно высокую точность попадания на позицию подразделения и большую разрушительную силу. Поэтому в статье представлено аналитическое выражение, которое описывается законом Пуассона и характеризует вероятность поражения элемента ВВТ одним осколком, что попал в него. Оно может быть использовано как для оченки поражающего действия осколочных боеприпасов на живучесть элементов объектов и легкобронированную технику подразделений так и для оценки поражающего действия осколочных боеприпасов на живучесть ВВТ в целом.

Ключевые слова: осколочные боеприпасы, легкобронированные машины, боеприпасы, вероятность поражения, вооружение и военная техника, закон Пуассона.

\section{THE INFLUENCE OF THE IMPRESSIVE EFFECT OF FRAGMENTAL AMMUNITION ON THE ELEMENTS OF OBJECTS AND LIGHTLY ARMORED EQUIPMENT OF UNITS}

\section{R. Litvinchuk, A. Levchenko, V. Klymenko}

The analysis of the conducted researches has shown that the most probable means of destruction of elements of objects and easily armored equipment of divisions are the artillery systems conducting fire by high-explosive ammunition. Including those that have a relatively high accuracy and high destructive power when hitting the unit. The probability of damage to the elements of the engine and combat compartment of lightly armored vehicles by a single fragment is usually determined experimentally, or by processing the accumulation during hostilities in statistics, as well as the method of natural physical modeling. These methods are complex, expensive and not always acceptable, as sufficient experimental data can be obtained only after prolonged combat use of Armament and military equipment. But unfortunately, during the Anti-terrorist Operation (Joint Forces Operation) such data were not recorded, and in peacetime, these methods do not meet the requirements of the military repair system. The method of natural modeling requires the production of accurate models of Armament and military equipment, which is unfavorable for economic reasons. In addition, they are unacceptable for new types of Armament and military equipment and are not suitable for newly constructed Armament and military equipment. Therefore, the article presents an analytical expression described by Poisson's law and characterizes the probability of damage to the element Armament and military equipment by one fragment that fell into it. It can be used to assess the impact of fragmentation munitions on the survivability of the elements of objects and easily armored vehicles of units, as well as to assess the impact of fragmentation munitions on the survivability of Armament and military equipment in general.

Keywords: fragmentation ammunition, lightly armored vehicles, ammunition, probability of defeat, Armament and military equipment, Poisson's law. 